\title{
norden
}

Pohjoismaiden neuvosto

Ved Stranden 18

DK-1061 København K

www.norden.org

NORDISKE ARBEJDSPAPIRER

POHJOISMAISET TYÖASIAKIRJAT

\section{EU:n rikkidirektiivin}

NA2013:923

http://dx.doi.org/10.6027/NA2013-923 


\section{EU:n rikkidirektiivin täytäntöönpano, seuraukset ja mahdollisuudet Pohjoismaissa}

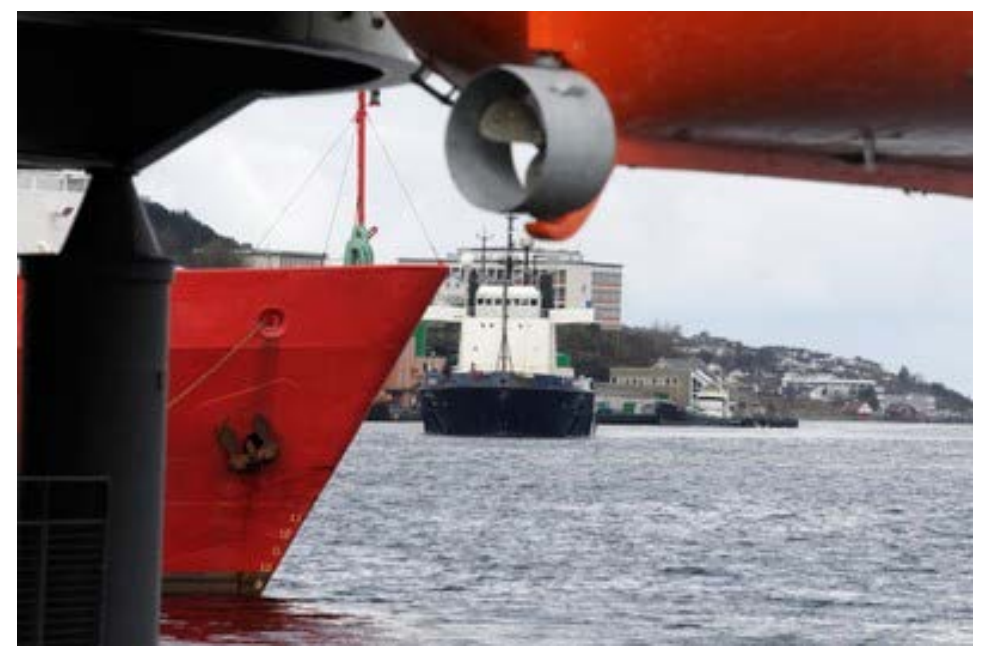

Valokuvaaja: Johannes Jansson - Norden.org

EU:n rikkidirektiiviä ja sen seurauksia käsittelevä Pohjoismaiden neuvoston työryhmä 


\section{Sisällys}

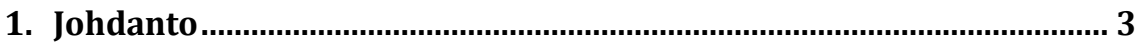

2. Tärkeimmät päätelmät .................................................................. 4

3. Mahdolliset tekniset ja muunlaiset ratkaisut....................................... 5

4. Rikkidirektiivin oletettu vaikutus.................................................. 9

5. Julkiset toimenpiteet rikkidirektiiviin sopeutumisen

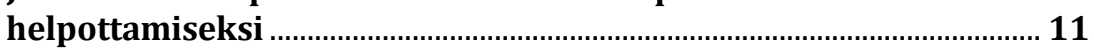

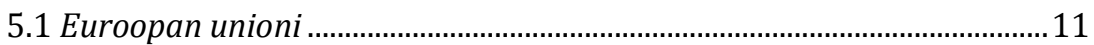

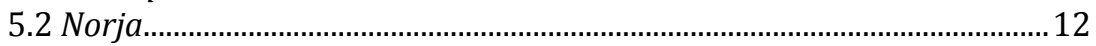

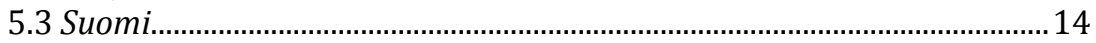

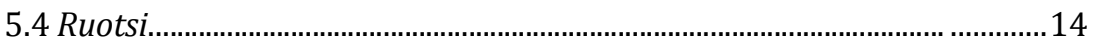

5.5 Tanska............................................................................................... 15

5.6 Muut Itämeren-maat........................ Fejl! Bogmærke er ikke defineret.

6. Päätelmät ja suositukset yhteispohjoismaisiksi

toimenpiteiksi ..........................................Fejl! Bogmærke er ikke defineret.

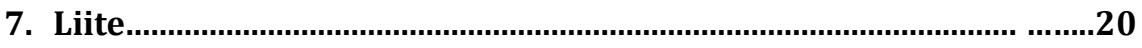

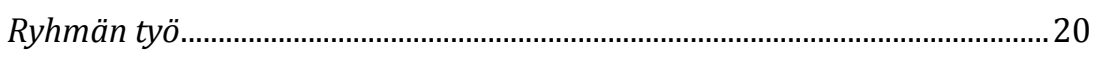

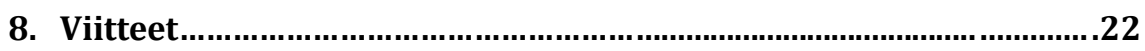




\section{Johdanto}

Meriliikenteessä käytettävien polttoaineiden rikkipitoisuutta koskevat vaatimukset kiristyvät 1. tammikuuta 2015 Itämerellä, Pohjanmerellä ja Englannin kanaalissa sekä Pohjois-Amerikan rannikolla ${ }^{1}$. Rikkipitoisuusraja laskee nykyisestä 1 prosentista 0,1 prosenttiin. Muilla merialueilla vaatimuksia kiristetään vasta vuonna 2020 , ja tuolloinkin rikkipitoisuuden rajaksi tulee 0,5 prosenttia $^{2}$. Vaihtoehto polttoaineen rikkipitoisuuden alentamiselle on, että aluksiin asennetaan saman standardin takaavat puhdistuslaitteistot.

Meriliikenteen päästöjä ilmaan säädellään kansainvälisesti MARPOLyleissopimuksella, jota hallinnoi Kansainvälinen merenkulkujärjestö IMO. EU hyväksyi marraskuussa 2012 MARPOL-yleissopimuksen mukaisen rikkipäästödirektiivin ${ }^{3}$.

Puhdistuslaitteistojen, uusien teknisten ratkaisujen tai vaihtoehtoisten polttoaineiden odotetaan parantavan sekä ympäristön tilaa että ihmisten terveyttä Itämeren alueella. Haittapuolena ovat meriliikenteelle aiheutuvat lisäkustannukset. Uudet vaatimukset ovatkin haaste Itämeren ympärysmaille. Näiden maiden teollisuus kilpailee globaaleilla markkinoilla, ja kuljetuskustannukset vaikuttavat kilpailutilanteeseen, kun samat tiukat määräykset eivät koske niiden kanssa kilpailevia alueita.

Uudet vaatimukset vaikuttavat neljään Pohjoismaahan, eli Norjaan, Ruotsiin, Suomeen ja Tanskaan. Pohjoismaiden neuvoston elinkeinovaliokunta ja ympäristö- ja luonnonvaravaliokunta pitivät tammikuussa 2013 Reykjavikissa yhteisen kokouksen, jossa päätettiin perustaa työryhmä tarkastelemaan uusia haasteita. Ryhmä koostuu seuraavista henkilöistä:

Oskar Grimstad (Norja), ympäristö- ja luonnonvaravaliokunta Anders Eriksson (Ahvenanmaa), ympäristö- ja luonnonvaravaliokunta Thomas Danielsen (Tanska), ympäristö- ja luonnonvaravaliokunta Billy Gustafsson (Ruotsi), elinkeinovaliokunta Eero Suutari (Suomi), elinkeinovaliokunta

\footnotetext{
${ }_{1}^{1}$ Asiantuntijapiireissä puhutaan SECA-alueesta, joka on lyhenne käsitteestä Sulphur Emission Control Area

2 Päätös on kuitenkin ehdollinen siten, että vuonna 2018 otetaan kantaa mahdolliseen uuteen ajankohtaan.

3 Euroopan parlamentin ja neuvoston direktiivi 2012/33/EU, annettu 21 päivänä marraskuuta 2012, neuvoston direktiivin 1999/32/EY muuttamisesta meriliikenteessä käytettävien polttoaineiden rikkipitoisuuden osalta.
} 
Työryhmä piti ensimmäisen kokouksensa Tukholmassa 10. huhtikuuta ja valitsi tuolloin ryhmän puheenjohtajaksi Oskar Grimstadin ja varapuheenjohtajaksi Anders Erikssonin. Pohjoismaiden neuvoston sihteeristön erityisasiantuntijat Johan Lindblad ja Tryggvi Felixson ovat työskennelleet ryhmän kanssa.

Työryhmä sai tehtäväksi arvioida Pohjoismaiden mahdollisia yhteisiä toimenpiteitä, joilla helpotetaan rikkidirektiivin täytäntöönpanon vaikutuksia merenkulkuun Itämerellä, Kattegatissa ja Pohjanmerellä, ja laatia ehdotus Pohjoismaiden neuvoston tätä koskevaksi aloitteeksi. Lisäksi sen tuli selvittää mahdollisuudet uusien tekniikoiden kokeilujaksoihin tai muihin siirtymäkauden ohjelmiin rikkidirektiivin tullessa voimaan vuonna 2015. Ryhmä totesi, ettei direktiivi anna mahdollisuutta kokeilujaksoihin 1. tammikuuta 2015 jälkeen. Tästä syystä ryhmä ei pitänyt tarkoituksenmukaisena jatkaa tehtävän tämän osion parissa, mistä se raportoi kummallekin valiokunnalle niiden kesäkokouksessa 2013.

\section{Tärkeimmät päätelmät}

Uusilla rikkipäästövaatimuksilla tulee olemaan suotuisa vaikutus ympäristöön ja terveyteen. Tämä on sopusoinnussa ympäristöpoliittisen perusperiaatteen kanssa, jonka mukaan saastuttaja maksaa ympäristövaikutuksesta tai sen rajoittamistoimista. Onneksi on olemassa uusia teknisiä ratkaisuja ja vaihtoehtoisia polttoaineita, joiden ansiosta meriliikenteellä on mahdollisuus sopeutua tilanteeseen. Uusien vaatimusten odotetaan myös edistävän teknistä kehitystä ja tarjoavan uusia mahdollisuuksia puhtaampiin tekniikoihin panostaville pohjoismaisille yrityksille.

Puhtaampien uusien tekniikoiden ja vaihtoehtoisten polttoaineiden käyttö kasvattavat käyttökustannuksia sekä lyhyellä että keskipitkällä aikavälillä. Suuri haaste alueen kilpailukyvylle on se, että rikkipäästömääräykset ovat suurimmassa osassa maailmaa lievemmät kuin Itämerellä, Kattegatissa ja Pohjanmerellä. Uusien rikkipäästömääräysten täytäntöönpanorasite ei myöskään jakaudu tasaisesti alueen sisällä. Jotkut Suomen ja Ruotsin alueet ja yritykset joutuvat oletettavasti pahoihin vaikeuksiin ilman tukitoimia. On myös todennäköistä, että tavaraliikennettä siirtyy mereltä maanteille, mikä on ympäristön kannalta epäsuotuisaa.

Uusien määräysten haittavaikutusten torjumiseksi työryhmä suosittelee,

että Pohjoismaiden hallitukset

- $\quad$ ryhtyvät toimenpiteisiin merenkulun kilpailukyvyn ylläpitämiseksi ja vahvistamiseksi 
- tekevät yhteistyötä luodakseen yhteiset säännöt nesteytetyn maakaasun (LNG) käytölle Pohjoismaissa ja kansainvälisesti

- laativat kansalliset suunnitelmat LNG-terminaalien perustamiseksi Pohjoismaiden satamiin

- pyrkivät edistämään meridieselin leimahduspistettä koskevien sääntöjen muuttamista tavallista dieseliä vastaaviksi

- pyrkivät EU:ssa, IMOssa ja muissa olennaisissa kansainvälisissä yhteyksissä siihen, että Itämerellä, Kattegatissa ja Pohjanmerellä sekä Pohjois-Amerikan rannikolla voimassa olevat rikkipäästösäännöt tulisivat mahdollisimman pian voimaan myös muilla merialueilla

- selvittävät maiden nykyisen aluskannan saadakseen käsityksen rikkidirektiivin täytäntöönpanon edellyttämien muutosten laajuudesta

- kehittävät norjalaisen NOx-rahaston kokemusten pohjalta taloudellisia kannustimia puhtaamman tekniikan käyttöönottamiseksi meriliikenteessä

että Ruotsin, Suomen ja Tanskan hallitukset sisällyttävät meriliikenteen infrastruktuurin, mukaan lukien LNG-terminaalien, rahoituksen EU:n rakennerahaston tuesta solmittaviin kumppanuussopimuksiin kaudella 20142020

että Norjan, Ruotsin ja Suomen hallitukset koordinoivat ja priorisoivat suunnitelmien toteuttamista pohjoisten alueiden raideliikennekapasiteetin vahvistamiseksi ja laajentamiseksi sekä rautatieyhteyksien rakentamiseksi SECA-alueen ulkopuolisiin satamiin Pohjoismaissa, kuten Narvikiin ja Trondheimiin

että Ruotsin ja Suomen hallitukset tutkivat, mitä seurauksia rikkidirektiivin täytäntöönpanolla on erityisen haavoittuville sektoreille rajoitetuilla maantieteellisillä alueilla, ja onko siirtymävaiheessa mahdollista käynnistää erityisiä alueellisia toimia, joiden avulla vältettäisiin rikkidirektiivin täytäntöönpanon kielteiset vaikutukset paikalliseen ja alueelliseen talouteen.

\section{Mahdolliset tekniset ja muunlaiset ratkaisut}

Ryhmä on keskustellut erilaisista teknisistä, taloudellisista ja infrastruktuurillisista ratkaisumahdollisuuksista, joilla voitaisiin yrittää lieventää rikkidirektiivin täytäntöönpanon kielteisiä vaikutuksia elinkeinoelämän kilpailuedellytyksille pahentamatta kuitenkaan Itämeren tai sen ympärysmaiden ympäristökuormitusta.

Sekä alan sisällä että yleisemmin on olemassa mahdollisia teknisiä ratkaisuja alusten rikkipäästöjen vähentämiseksi. Jäljempänä kuvaillaan useita tällaisia ratkaisuja. 


\section{Rikkipesurit}

Rikkipesuri on suhteellisen yksinkertainen ja huokea ratkaisu, jota voitaisiin käyttää vanhahkoissa aluksissa. Pesuritekniikka perustuu siihen, että aluksen polttoaineena käytettävästä perinteisestä raskaasta polttoöljystä syntyvät pakokaasupäästöt puhdistetaan. Jäämä voidaan varastoida satamaan tai upottaa mereen ${ }^{4}$. Jälkimmäinen vaihtoehto on ympäristönäkökulmasta sopimaton, mutta satamavarastointi olisi mahdollista, mikäli satamissa olisi infrastruktuuri tällaisen jätteen vastaanottoon ja käsittelyyn tai pois kuljettamiseen. Vielä sitä ei kuitenkaan ole. Rikkipesuritekniikan ensisijainen ongelma on kuitenkin todennäköisesti se, että pesurit ovat suurikokoisia ja vievät siten tärkeää tilaa aluksen rahdilta. Ne myös haittaavat aluksen vakautta. Vaikka rikkipesuritekniikka mainitaankin mahdollisena teknisenä ratkaisuna, se ei vaikuta pitemmän päälle todennäköisimmältä ratkaisulta alalla.

\section{Nesteytetty maakaasu (LNG)}

Nesteytetty maakaasu on polttoaineena sellaisenaan vähärikkistä. Jäähdytetty kaasu ei myöskään vie erityisen paljon tilaa eikä syty helposti. Alan sisällä LNG mainitaan tulevaisuuden ensisijaisena polttoaineena meriliikenteessä, mutta toistaiseksi ei ole olemassa toimivaa infrastruktuuria LNG:n toimittamiseen aluksille ja satamiin. On myös vaikea muuntaa vanhoja aluksia LNG-käyttöisiksi, mutta suuntaus on se, että uudet alukset rakennetaan käyttämään LNG:tä. Lähes 20 prosenttia aluksista on 30-40 vuoden ikäisiä, ja ne saatetaan korvata uusilla vuosiin 2015-2020 mennessä. Uusille LNGkäyttöisille aluksille on siis potentiaalia.

Viking Line on panostanut LNG:hen Tukholman ja Turun väliä liikennöivässä uudessa Viking Grace -aluksessaan. LNG:n tankkaus voi tapahtua toisesta aluksesta käsin merellä tai laiturissa, putkistoa pitkin tai suoraan säiliöautosta. Viking Line ilmoittaa LNG:hen siirtymisen vähentäneen polttoaineen kulutusta 70 prosenttia ${ }^{5}$. LNG:n tankkausta koskevat määräykset kuitenkin puuttuvat, mutta asiaa tarkastellaan Euroopan tasolla. Ei ole myöskään olemassa selkeitä määräyksiä LNG:n tankkauksesta, kun matkustajat ovat aluksessa.

LNG-käyttöisiksi rakennetuissa aluksissa voi tulevaisuudessa käyttää myös biokaasua. LNG:stä ei myöskään synny jätettä, ja kasvihuonekaasupäästöt vähenevät 15 prosenttia. Myös polttoaineen käsittely aluksella on puhtaampaa ja yksinkertaisempaa verrattuna raskasta polttoöljyä käyttäviin aluk-

\footnotetext{
${ }^{4}$ On odotettavissa, että jäämien upottamista mereen tullaan sääntelemään.

${ }^{5}$ Norjan varustamoyhdistyksen edustaja totesi työryhmän 24. kesäkuuta pitämässä kokouksessa, että tutkimuksen mukaan nesteytetty maakaasu meriliikenteen polttoaineena poistaa hiukkas- ja rikkipäästöt kokonaan, vähentää hiilidioksidipäästöjä 15-20 prosenttia ja typen oksidien päästöjä 90 prosenttia.
} 
siin. LNG:n käsittelyyn liittyvä koulutus kuitenkin puuttuu, samoin määräykset LNG:n käsittelystä maissa.

Nykyään LNG:tä on saatavilla vain Pohjoismaiden suurissa satamissa, sillä sen toimittaminen pienille satamille on liian kallista. Pienten LNGterminaalien perustamista kuitenkin tutkitaan. Alan arvioiden mukaan merenkulun toimijat eivät suoriudu yksinään laajamittaisesta siirtymisestä LNG:n käyttöön. Myös teollisuuden on ryhdyttävä käyttämään LNG:tä vaihtoehtona hiilelle ja ydinvoimalle, muun muassa siksi, että sen saatavuus yhteiskunnassa paranisi. Joissakin maissa (erityisesti Ruotsissa) poliitikot suhtautuvat samalla penseästi suurpanostukseen LNG:hen polttoaineena, koska uuteen riippuvuuteen fossiilisista polttoaineista ei ylipäätään haluta investoida. Jäljempänä olevasta kartasta näkyy, missä on tällä hetkellä olemassa tai suunnitteilla LNG-terminaaleja ja tankkausmahdollisuuksia.

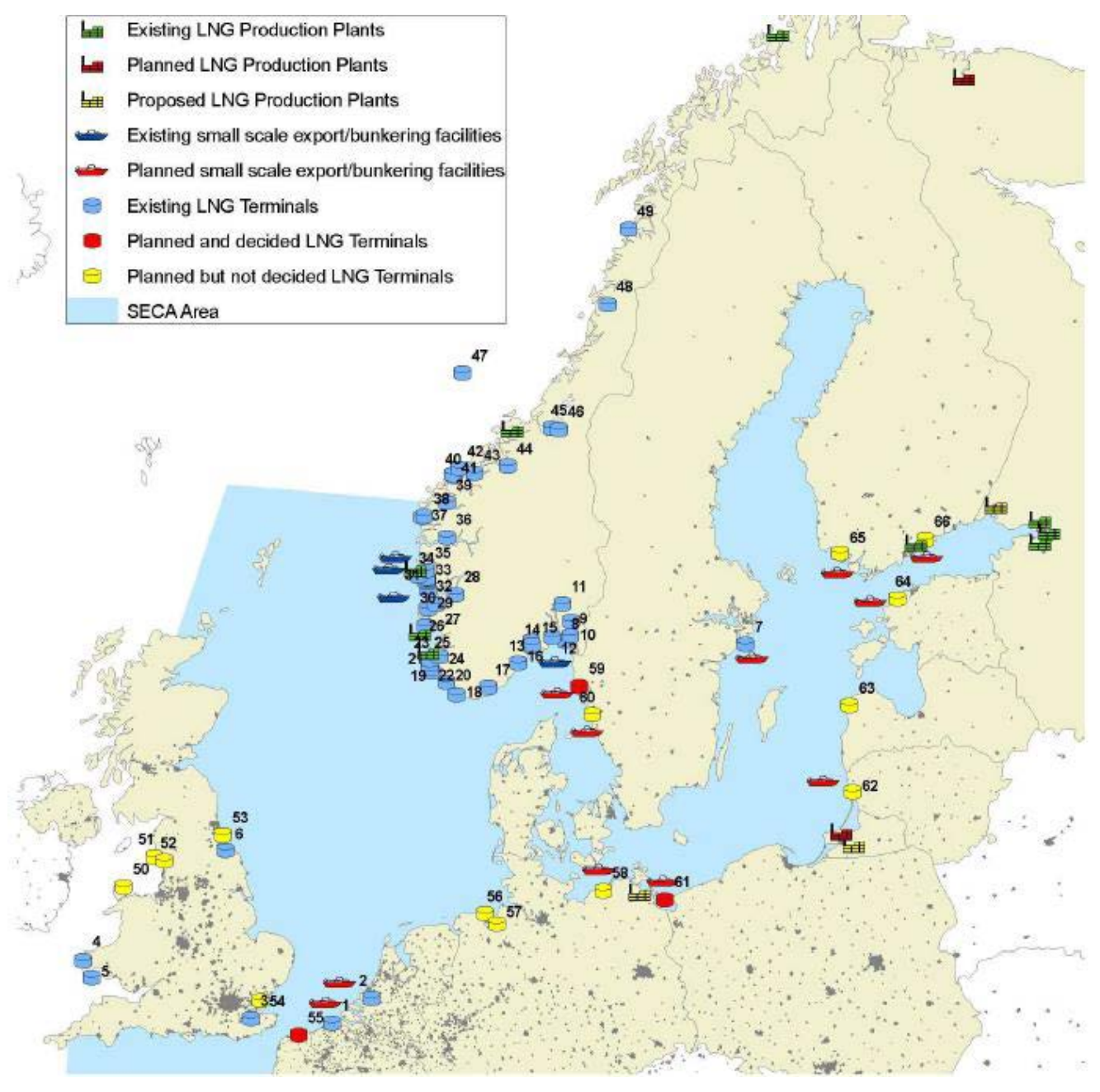

\section{Meriliikenteessä käytettävä dieselöljy}

Vaihtoehtona meriliikenteessä nykyisin pääasiallisesti käytettävälle polttoaineelle eli raskaalle polttoöljylle voitaisiin lisätä meridieselin käyttöä. Meridiesel on kuitenkin huomattavasti raskasta polttoöljyä kalliimpaa, ja uh- 
kana on sitä paitsi sen raju hinnankorotus tulevaisuudessa. Meridieselin hintapaineen pienentämiseksi voitaisiin lieventää määräystä meridieselin leimahduspisteestä ja alentaa sitä nykyisestä 60 celsiusasteesta 52 celsiusasteeseen, joka koskee tavallista tieliikenteessä käytettävää dieselöljyä. Siirtyminen erityisestä meridieselistä tavalliseen dieselöljyyn myös meriliikenteessä tasoittaisi sitä paitsi tiekuljetusten ja merikuljetusten välisiä kilpailuedellytyksiä. Sitä mukaa kuin liuskeöljyn tuotanto kasvaa ja autokanta sähköistyy myös dieselin hinta ja kysyntä laskevat merenkulun eduksi. Pitemmän päälle dieselöljy ei kuitenkaan ole ympäristön kannalta paras mahdollinen polttoaine.

\section{Metanoli ja biopolttoaine}

Myös metanoli on mahdollinen tulevaisuuden polttoaine, mutta sen syttymisriski on suurempi, sillä leimahduspiste on alhainen, vain 12 celsiusastetta. Biopolttoaine puolestaan voi todennäköisesti olla tulevaisuuden polttoaine, sillä sitä voi käyttää samoissa polttoainejärjestelmissä kuin LNG:tä. Biopolttoaineen tarjonta on kuitenkin toistaiseksi liian vähäinen.

Polttoaineen vaihtamisen tai muiden teknisten muutosten ohella voidaan kilpailukyvyn heikentymistä torjua myös panostamalla muihin kuljetusmuotoihin tai infrastruktuureihin. Mikään näistä vaihtoehdoista ei kuitenkaan ole ympäristönäkökulmasta toivottava.

\section{Rautatiekuljetusten lisääminen}

Yksi mahdollinen ratkaisu sekä ympäristö- että kilpailutilanteeseen olisi tavaraliikenteen siirtäminen entistä suuremmassa määrin mereltä raiteille. Esimerkiksi itä-länsi-suunnassa, sillä Narvikin ja Trondheimin satamat ja niiden ulkopuoliset merialueet eivät kuulu SECA-rajoitusten piiriin, toisin kuin Itämeri, Kattegat, Skagerrak ja Pohjanmeren eteläosat. Tämä on kuitenkin lyhyellä aikavälillä mahdotonta, sillä monilla näistä reiteistä on pulaa kapasiteetista, ja investointikustannukset ovat liian suuret ja projektointiajat liian pitkät, jotta elinkeinoelämän kilpailutilanne voitaisiin ratkaista tällä tavalla lyhyellä aikavälillä.

\section{Tiekuljetusten lisääminen}

Yksi mahdollinen seuraus rikkidirektiivin voimaantulosta on se, että kuljetukset siirtyvät entistä suuremmassa määrin mereltä maanteille. Vaikka tämä saattaisikin helpottaa kilpailutilannetta, ympäristönäkökulmasta tällaista kehitystä on syytä vastustaa. Lisäksi tarvittaisiin valtava määrä rekkoja kuljettamaan sama rahtimäärä, joka mahtuu keskikokoiseen alukseen. Poliittisesti kuljetusten siirtymistä mereltä maalle voitaisiin torjua erilaisilla maksuilla, kuten rekkojen satamamaksuilla ja tiemaksuilla, joilla tasoitettaisiin tie- ja merikuljetusten kustannuseroa. Tämä ei kuitenkaan edistä pohjoismaisten yritysten kilpailutilannetta. 


\section{Puhtaiden alusten suosiminen}

Esimerkiksi Ruotsi palkitsee väylämaksuilla siirtymistä puhtaampiin polttoaineisiin ja tekniikoihin. Tällaisella kannusteella voidaan nopeuttaa muutosta, mutta pitemmällä aikavälillä se ei vaikuta kilpailutilanteeseen SECAalueen sisällä, sillä samat päästömääräykset koskevat kaikkia aluksia.

\section{Rikkidirektiivin oletettu vaikutus}

HELCOMin mukaan Itämeren meriliikenteen kasvu lisää huomattavasti sekä ilman että veden epäpuhtauksia Itämeren alueella. Rikkidioksidipäästöt $\left(\mathrm{SO}_{2}\right)$ ovat peräisin polttoaineesta, joka sisältää sekä ympäristölle että terveydelle haitallista rikkiä ja pienhiukkasia ${ }^{6}$. Meriliikenne aiheuttaa myös merkittäviä typen oksidien päästöjä, mikä HELCOMin mukaan pahentaa Itämeren rehevöitymistä. Meriliikenteellä on muitakin haittavaikutuksia, kuten hiilidioksidin, otsonikatoa aiheuttavien aineiden ja VOC-yhdisteiden (haihtuvat orgaaniset yhdisteet) päästöt. Kaikki nämä haittavaikutukset vähenevät huomattavasti tiukempien vaatimusten tullessa voimaan vuonna 2015.

Lyhyellä aikavälillä liikennesektorit eivät pysty ottamaan käyttöön uusia teknisiä ratkaisuja. Sen vuoksi suurimman osan Itämerellä liikennöivistä aluksista odotetaankin siirtyvän vuonna 2015 raskaasta polttoöljystä vähärikkiseen meridieseliin. Se on kalliimpaa kuin nykyisin käytettävä polttoaine. Uudet määräykset johtavat dieselöljyn kysynnän kasvuun. Vähärikkisen dieselöljyn hinnan odotetaan sen vuoksi kohoavan ${ }^{7}$. Meridieselin leimahduspisteen on oltava 60 astetta. Tavallisen dieselöljyn leimahduspiste on 52 celsiusastetta, eikä sitä tästä syystä saa käyttää meriliikenteessä. Tämä vaikuttaa osaltaan meridieselin hinnankorotuspaineeseen ${ }^{8}$.

Meriliikenne pystyy lyhyellä aikavälillä sopeutumaan korkeampiin hintoihin vähentämällä polttoaineen kulutusta. Se voidaan toteuttaa muun muassa alentamalla nopeutta. Pitkällä aikavälillä sopeutuminen tapahtuu uusilla teknisillä ratkaisuilla ja vaihtoehtoisilla polttoaineilla. Vaikka tehokkuuden paraneminen ja uudet tekniset ratkaisut korvaavatkin osan lisäkustannuksista, meriliikenteen suhteellinen kilpailutilanne heikkenee silti. Osa kuljetuksista siirtyy rautateille ja osa maanteille, mikä aiheuttaa ympäristöhaitto-

\footnotetext{
${ }^{6} \mathrm{http}: / /$ www.helcom.fi/shipping/emissions/en_GB/emisions/

${ }^{7}$ Meriliikenteen polttoaineiden rikkipitoisuuden kiristyvien vaatimusten seurauksia käsittelevässä raportissa Konsekvenser av skärpta krav för svavelhalten i marint bränsel - delredovisning (Trafikanalys, rapport 2013:7) arvioidaan, että nykyisen polttoaineen ja vähärikkisen polttoaineen hintaero tulee olemaan 50-75 prosenttia.

${ }^{8}$ Asiaa käsiteltiin IMOn meriturvallisuuskomiteassa (92. kokous) USAn ehdotuksen pohjalta. USAn kokouksessa esittämän dokumentoinnin nojalla meridieselin ja tavallisen dieselin erilaiselle leimahduspisteelle ei ole asiallista perustetta.
} 
ja. Rautateiden kapasiteetti on rajoitettu, mutta sitä voidaan kasvattaa vähitellen sekä vahvistamalla nykyisiä rataosuuksia että rakentamalla uusia ${ }^{9}$.

EU-komission vuodelta 2010 olevassa raportissa ${ }^{10}$ todetaan, että on olemassa teknisiä ratkaisuja, jotka yhdessä muiden toimenpiteiden kanssa voivat vähentää laivaliikenteen kasvavia hiilidioksidi- ja rikkidioksidipäästöjä. Analyysien mukaan yhteiskunta hyötyy yleisesti päästöjen vähentämisestä, sillä se vaikuttaa suotuisasti sekä ympäristöön että terveyteen. Kustannukset ja hyöty eivät kuitenkaan välttämättä jakaudu tasaisesti. Alustavan ruotsalaisarvion mukaan kuljetusten kokonaiskustannukset kohoavat 2,4 miljardia 4,6 miljardiin Ruotsin kruunuun. Arvion mukaan ei ole varmaa, että Ruotsin ympäristöhyöty on oikeassa suhteessa kustannuksiin, ainakin jos ei lasketa mukaan eteläistä Ruotsia11.

Tiukentuvien vaatimusten suotuisa vaikutus ei rajoitu ympäristöön ja terveyteen. Pohjoismaiden meriteollisuudella on näköpiirissään uusiin teknisiin ratkaisuihin liittyviä uusia mahdollisuuksia. Alueesta voi tulla myöhemmin muuallekin maailmaan leviävien uusien tekniikoiden testauksen edelläkävijä. Tämä loisi uusia mahdollisuuksia ja työpaikkoja.

Uusien määräysten kaikkien vaikutusten hahmottamiseksi asiaa on tarkasteltava sekä maantieteellisesti että sektoreittain. Kuljetuskustannuksilla on erityisen suuri merkitys joillekin maantieteellisille alueille ja sektoreille. Tämä koskee ennen kaikkea Pohjois-Ruotsin ja Pohjois-Suomen metalli- ja paperiteollisuutta.

\footnotetext{
${ }^{9}$ Pohjoismaiden neuvosto hyväksyi vuonna 2012 suosituksen Ofotenin radan kunnostamisesta ja laajentamisesta niin, että se mahdollistaisi kuljetukset myös Suomesta Narvikiin.

${ }^{10}$ Regulating Air Emissions from Ships.

${ }^{11}$ Konsekvenser av skärpta krav för svavelhalten i marint bränsel - delredovisning (Trafikanalys, rapport 2013:7)
} 

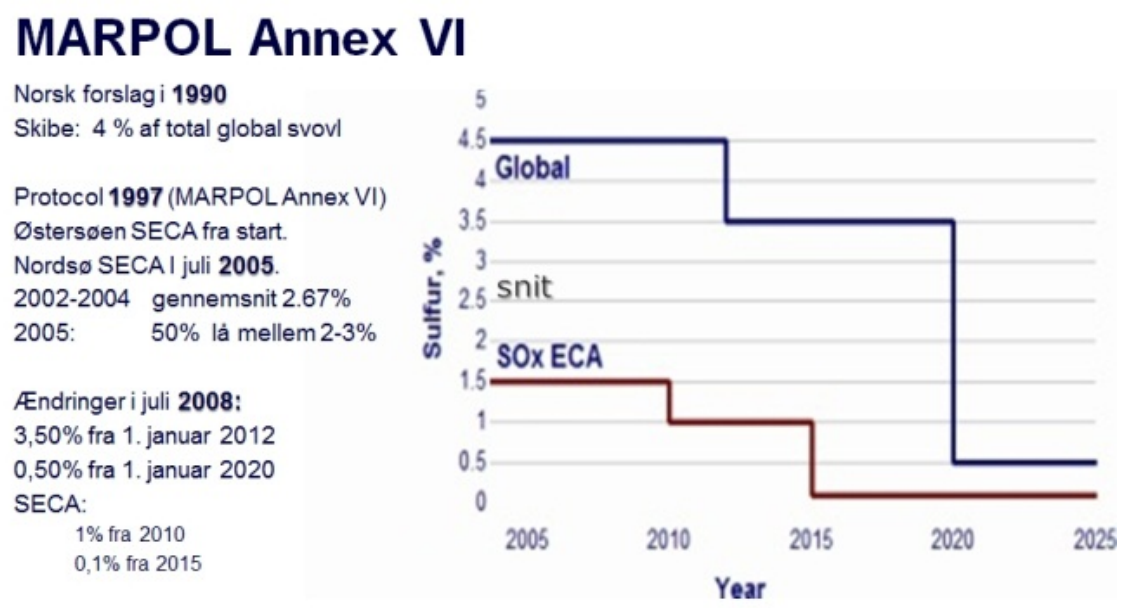

Yllä oleva Danske Maritimen ${ }^{12}$ kaavio kuvaa merenkulun rikkipäästömääräysten tiukentumista. SECA-alueen (Itämeri, Kattegat ja Pohjanmeri sekä Pohjois-Amerikan rannikko) nykyinen päästöraja on $1 \%$, muualla se on 3,5\%. Merenkulun keskimääräinen rikkipäästötaso on kaiken kaikkiaan 2,5\% eli kansainvälisiä vaatimuksia alhaisempi. SECA-aluetta koskeva raja laskee 0,1 prosenttiin vuonna 2015, ja kansainvälinen raja 0,5 prosenttiin vuonna 2020.

\section{Julkiset toimenpiteet rikkidirektiiviin sopeutumisen helpottamiseksi}

\subsection{Euroopan unioni}

\section{Ten-T}

EU:lla ei ole rikkidirektiivin voimaantuloon erityisesti kohdennettua tukiohjelmaa. EU:n Euroopan laajuiseen liikenneverkkoon TENiin sisältyy kuitenkin rahoitusohjelma, jota jäsenmaat voivat hyödyntää. Kaudella 2007-2013 tähän tarkoitukseen myönnettiin kahdeksan miljardia euroa, ja komissio, parlamentti ja neuvosto ovat sopineet äskettäin uudesta, vuoteen 2020 ulottuvasta ohjelmakaudesta ${ }^{13}$. Hakuja on ollut vuosittain, ja viimeisin päättyi helmikuussa 2013. Osa tuesta on myönnetty meriliikenteelle, mitä monet

\footnotetext{
12 Ote ryhmän Kööpenhaminassa 28. elokuuta pidetyssä kokouksessa olleesta esityksestä. 13 Ote lehdistötiedotteesta: The new core TEN-T network will be supported by a comprehensive network of routes, feeding into the core network at regional and national level. This will largely be financed by Member States, with some EU transport and regional funding possibilities, including with new innovative financing instruments. The aim is to ensure that progressively, and by 2050, the great majority of Europe's citizens and businesses will be no more than 30 minutes' travel time from the comprehensive network.
} 
Itämeren-maat ovat hyödyntäneet. Esimerkkinä mainittakoon tuki Itämeren alueen LNG-infrastruktuurin yhdenmukaistamista koskevalle selvityshankkeelle, jossa ovat mukana Århusin, Helsingborgin, Helsingin, MalmöKööpenhaminan, Tallinnan, Turun ja Tukholman satamat ${ }^{14}$. Puolet tämän 3,4 miljoonan euron pre-investment studyn rahoituksesta tulee TEN-T:stä. Hankkeen kuvaukseen sisältyy useita Itämeren meriliikennettä koskevia hankkeita.

\section{Rakennerahastot}

Myös EU:n aluekehitysrahastoa (ERDF) ${ }^{15}$ voi periaatteessa käyttää infrastruktuurin rahoittamiseen Suomessa, Ruotsissa ja Tanskassa. Parhaillaan ollaan kehittämässä kansallisia ohjelmia sekä rakennerahastoja koskevia jäsenmaiden ja EU:n välisiä kumppanuussopimuksia kaudelle 2014-2020. Infrastruktuuri-investoinnit merenkulun ympäristövaikutusten vähentämiseksi ovat oikeutettuja tukeen, samoin toimenpiteet kaupunkien ja alueiden välisen meriliikenneyhteistyön lisäämiseksi. Yksi edellytys on se, että hankkeet sisältyvät kansallisiin suunnitelmiin sekä EU- komission kanssa solmittuihin kumppanuussopimuksiin.

\section{Marco Polo ja EIP}

EU-komission valmisteluasiakirjassa ${ }^{16}$ viitataan myös Marco Polo II:een ja Euroopan investointipankkiin mahdollisina eurooppalaisina rahoituslähteinä.

\subsection{Norja}

\section{NOx-rahasto}

Viisitoista elinkeinoelämän järjestöä perusti Norjassa vuonna 2008 rahaston, jonka tarkoituksena on vähentää typen oksidien päästöjä. NOxmaksuvelvolliset yritykset, jotka liittyvät rahastoon, välttyvät maksamasta NOx-maksua valtiolle maksamalla saman summan rahastoon. Kaikki rahastoon kertyvät varat käytetään typen oksidien päästöjen vähentämiseen. EU on arvioinut rahaston toiminnan, eikä katso sen vääristävän kilpailua ${ }^{17}$.

\footnotetext{
${ }^{14}$ Lähde: http://tentea.ec.europa.eu/en/home/

15 Lähde: http://ec.europa.eu/regional_policy/thefunds/regional/index_en.cfm

The ERDF aims to strengthen economic and social cohesion in the European Union by correcting imbalances between its regions. In short, the ERDF finances: direct aid to investments in companies (in particular SMEs) to create sustainable jobs; infrastructures linked notably to research and innovation, telecommunications, environment, energy and transport; financial instruments (capital risk funds, local development funds, etc.) to support regional and local development and to foster cooperation between towns and regions; technical assistance measures.

16 Commission Staff Working Paper,"Pollutant Emission Reduction from Maritime Transport and the Sustainable Waterborne Transport Toolbox", Brussel 16.9.2011.

17 Tukea myönnetään toimenpiteisiin, jotka väh entävät päästöjä alle laissa säädettyjen rajojen. Tämä on sidoksissa valtiontukea koskeviin määräyksiin, joiden mukaan tukea ei voi saada nykyisten vaatimusten täyttämiseen. Meriteollisuusmääräysten piiriin kuuluvat yritykset eivät voi saada NOx-rahastolta tukea mahdollisten Tier III -vaatimusten tultua voimaan. Tier III -vaatimusten piiriin kuulumaton muu toiminta voi edelleen saada tukea NOx-rahastosta. Tier III on poliittisella tasolla määritelty raja sille, minkä verran muu
} 
Rahastolla on kapasiteettia jakaa noin 80 miljoonaa euroa vuodessa Norjan aluevesillä purjehtivien alusten ja maissa sijaitsevien teollisuuslaitosten investointeihin. Kyseeseen voivat tulla rahaston jäsenenä olevat noin 650 yritystä. Noin puolet tuesta on myönnetty LNG:hen siirtymiseen, ja tukea on saanut yli 50 LNG-käyttöistä alusta.

\section{Rahasto voi tukea muun muassa:}

- Uusien kaasukäyttöisten alusten rakentamista ja olemassa olevien alusten muuntamista kaasukäyttöisiksi

- LNG-infrastruktuuria

- Typen oksidipäästöjä vähentäviä uusia, lupaavia toimenpiteitä

- SCR-puhdistustustekniikkaa, joissa urea käytetään aluksella

- SCR- ja SNCR-tekniikkaa jätteenpolttoteollisuudessa

- Sähkökäyttöisiä lauttoja ja muita matkustaja-aluksia

- Kaasuteollisuutta

- Moottorin muuntamista vähätyppisiksi

- Moottorin vaihtamista

Useimmissa tapauksissa rahasto rahoittaa noin 80 prosenttia investointikustannuksista, mikäli päästövähennyskriteerit täyttyvät.

Rahasto on auttanut vähentämään typen oksidipäästöjä vuosittain 19000 tonnia vastaavalla määrällä, ja vuonna 2017 määrän odotetaan kohoavan 16 000 tonnilla 18

\section{Tuki LNG-terminaaleille}

Norjan öljy- ja energiaministeriön omistama Enova voi tukea maakaasuinfrastruktuurin rakentamista 30 miljoonalla kruunulla vuodessa. Kyse on erityisestä valtion budjettierästä, joka pidetään erillään Enovan energiarahastosta.

Saatuaan hakemuksen Gasnorilta Enova päätti keväällä 2013 rahoittaa 25 prosenttia Östfoldiin lähelle Sarpsborgia rakennettavan LNG-laitoksen investointikustannuksista. Ajatuksena on, että Gasnorin laitos voisi muutaman vuoden kuluttua vastata Itä-Norjan ja osittain myös Länsi-Ruotsin teollisuuden LNG-huollosta. Norjassa on LNG-terminaalit myös sekä Stavangerin että Fredrikstadin lähellä. 


\subsection{Suomi}

\section{Investointituki aluksille ${ }^{19}$}

Suomalaiset varustamot voivat hakea tukea investointihankkeisiin, joilla on merkittävästi ympäristöä parantava vaikutus. Tämän vuoden huhtikuusta lähtien tuki koskee myös jo käytössä olevia aluksia. Tuki kohdistuu pakokaasupäästöjen, erityisesti rikkipäästöjen puhdistustekniikkoihin. Investointien avulla voidaan siirtyä käyttämään vaihtoehtoisia, puhtaampia polttoaineita tai puhdistaa pakokaasupäästöjä. EU on hyväksynyt tukiohjelman, mikäli sen osuus ei ylitä 50 prosenttia investointikustannuksista. Vuoden 2013 valtion budjetissa tukeen on varattu 30 miljoonaa euroa.

\section{Tuki LNG-terminaaleille 20}

Suomen valtio on varannut 100 miljoonaa euroa LNG-terminaalien investointitukeen vuosina 2013 ja 2014. Suomi on jo tehnyt päätöksen tuesta, mutta asia on parhaillaan käsiteltävänä EU-komissiossa, jonka on varmistettava, että tuki on EU:n valtiontukisääntelyn mukainen. Ohjelman odotetaan tulevan voimaan syyskuussa. Ohjelma on kehitetty energia-alan toimenpiteenä21.

\subsection{Ruotsi}

\section{Väylämaksut}

Ruotsin merenkulkuviranomainen on määrännyt aluksille eriytettyjä väylämaksuja vuodesta 2004 lähtien. Tarkoituksena on luoda taloudelliset kannusteet alusten ympäristöhaittojen vähentämiselle. Alukset, joiden polttoaineen rikkipitoisuus on alle 0,5 prosenttia, saavat huomattavan alennuksen maksusta, ja jos rikkipitoisuus on alle 0,2 prosenttia, alus vapautetaan maksusta. Myös alukset, joilla on laitteisto typen oksidipäästöjen vähentämiseen, saavat reiteillä alennusta väylämaksuista asteikolla $10 \mathrm{~g} / \mathrm{kWh}-0,4$ $\mathrm{g} / \mathrm{kWh}$, jolloin alus välttyy maksulta kokonaan.

\section{Tuki LNG-terminaaleille}

Ruotsin hallitus hyväksyi maaliskuussa 2013 EU-tukihakemuksen LNGterminaalin perustamiseksi Göteborgin satamaan. Tavoitteena on, että terminaali aloittaisi toimintansa vuonna 2015. LNG-terminaali voisi palvella sekä merenkulkua että Länsi-Ruotsin teollisuutta. Panostuksesta vastaavat muun muassa Swedegas sekä Göteborgin ja Rotterdamin satamat, jotka ovat perustaneet kumppanuuden panostaakseen LNG:hen tulevaisuuden polttoaineena meriliikenteessä.

\footnotetext{
${ }^{19}$ Lähde: http://www.lvm.fi/tiedote/4142361/alusten-investointituesta-helpotusta-rikkipaastorajoihinsopeutumiseen

20 Lähde: http://www.tem.fi/energia/lng-terminaalien investointituki

21 Tämän tyyppiset investoinnit ovat EU:n kansallisen aluetukisääntöjen 2007-2013 alaisia (OJ C 54, 4.3.2006)
} 


\subsection{Tanska}

\section{Kumppanuus}

Tanskassa ei ole erityisiä merenkulun tukiohjelmia, jotka kohdistuisivat rikkipäästöjen tai typen oksidipäästöjen vähentämiseen ${ }^{22}$. Sen sijaan ympäristöministeriö ja Tanskan varustamoyhdistys ovat perustaneet kumppanuuden puhtaamman merenkulun puolesta (Partnerskap for Renere Skibsfart ${ }^{23}$ ), jonka tavoitteena on muun muassa vähentää laivaliikenteen päästöjä. Kumppanuuden työsuunnitelmassa on nimetty joitakin mahdollisia toimenpiteitä, joista useimmat tähtäävät teknisten ratkaisujen kehittämiseen ja kokeilemiseen.

\section{Tuki LNG:Ile}

Tanskan merenkulkuviranomainen on käynnistänyt paikallisten ja alueellisten osapuolten kanssa vuoropuhelun, jonka tarkoituksena on saada aikaan konkreettisia LNG-esittelyhankkeita. On myös käynnistetty hanke Itämeren alueen LNG-tankkausasemien yhdenmukaisesta kehittämisestä. Mukana on yhdeksän Itämeren satamaa, muun muassa Malmö-Copenhagen Port sekä Århusin satama.

\section{Valvonta}

Varmistaakseen uusien vaatimusten toteutuksen ja turvatakseen kaikille varustamoille yhtäläiset kilpailuedellytykset Tanska on kehittänyt automaattisia mittauslaitteita, jotka havaitsevat päästömääräyksiä noudattamattomat alukset.

\subsection{Muut Itämeren-maat}

Muiden Itämeren-maiden suunnitelluista tai toteutetuista toimenpiteistä ja tukiohjelmista on vaikea saada tietoa. Voidaan kuitenkin todeta, ettei Viro ole ryhtynyt toimenpiteisiin. Saksassa on mahdollista saada korkotuellista lainaa ja tukea alusten puhdistuslaitteistojen kehittämiseen ${ }^{24}$. Vaikuttaa siltä, että esimerkiksi Latvia ja Puola ovat huolissaan rikkidirektiivin täytäntöönpanon seurauksista, mutta että ne ovat havahtuneet liian myöhään ehtiäkseen ryhtyä mainittaviin toimenpiteisiin.

\footnotetext{
22 Lähde: Reducing Air Pollution from Ships, Danish Ministry of the Environment, 2012 23

http://www.ecoinnovation.dk/Emneoversigt/Partnerskaber_miljøteknologi/Partnerskabet_for_renere_skibs fart/Ambitioes_handlingsplan.htm

${ }^{24}$ Lähde: Raportti Konsekvenserna av skärpta krav för svavelhalten i marint bränsel - delredovisning, Rapport 2013:7, Trafikanalys sekä virolaiset ja saksalaiset tahot.
} 


\section{Päätelmät ja suositukset yhteispohjoismaisiksitoimenpiteiksi}

Uudet rikkipäästövaatimukset ovat suotuisien ympäristö- ja terveysvaikutusten vuoksi väistämättömiä ja tervetulleita. Uusien vaatimusten odotetaan myös edistävän teknistä kehitystä. Tämä on myös sopusoinnussa ympäristöpoliittisen perusperiaatteen kanssa, jonka mukaan saastuttaja maksaa ympäristövaikutuksesta tai sen rajoittamistoimenpiteistä. Suuri haaste alueen kilpailukyvylle on se, että rikkipäästömääräykset ovat suurimmassa osassa maailmaa lievemmät kuin Itämerellä, Kattegatissa ja Pohjanmerellä. Merikuljetukset ovat ympäristön kannalta myönteinen vaihtoehto tiekuljetuksille. Sen vuoksi tuleekin välttää kuljetusten siirtymistä mereltä maanteille.

Eri Pohjoismaissa on esitetty erilaisia arvioita päästövaatimusten täyttämisen vaikeudesta. Norjassa ja Tanskassa arvioidaan, että uudet päästömääräykset on mahdollista toteuttaa ilman merkittäviä seurauksia liikenne- ja vientisektoreille ${ }^{25}$. Ruotsissa ja Suomessa ollaan hyvin huolestuneita kuljetuskustannusten tuntuvasta kohoamisesta ja sen vakavista seurauksista kilpailutilanteelle, erityisesti metalli-, metsä- ja kaivosteollisuudessa, jotka sijoittuvat maiden pohjoisosiin. Kyseiset sektorit vievät suurimman osan tuotannostaan, kuljetuskustannukset ovat merkittävä menoerä ja alat toimivat globaalein markkinahinnoin. Pitkällä aikavälillä rautatieverkon laajentaminen ratkaisee kuljetustarpeen, mutta sitä ennen uudet määräykset saattavat vaikuttaa vakavasti paikalliseen elinkeinoelämään. Erityisen haavoittuvien sektoreiden ja maantieteellisten alueiden lyhyen aikavälin sopeutumisen helpottamiseen kohdennettuja toimenpiteitä tai toimenpidesuunnitelmia ei ole ${ }^{26}$. Vaikutusselvitys on edellytys mahdollisten toimenpiteiden arvioimiselle ${ }^{27}$.

Ahvenanmaalla merenkulku muodostaa suuren osan BKT:sta, ja kaikki merenkulun kilpailutilanteen muutokset arvioidaan tästä näkökulmasta.

\footnotetext{
${ }^{25}$ Norjan varustamoyhdistys on todennut lausunnossaan, ettei se kannata EU-direktiivin lykkäämistä, koska se voisi vääristää kilpailua niiden varustamojen osalta, jotka jo noudattavat määräyksiä ja koska se heikentäisi IMOn auktoriteettia ja asemaa meripolitiikka-alan lakia säätävänä elimenä.

${ }^{26}$ Ruotsin merenkulkulaitoksen raportissa vuodelta 2009 on luettelo mahdollisista vaikutuskeinoista, mukaan lukien tuki tietyille satamille (Perämerellä), investointituki, väylämaksujen alentaminen, veroton sähköhuolto aluksille.

27 Raportissa Konsekvenserna av skärpta krav för svavelhalten i marint bränsel - delredovisning, rapport 2013:7 mainitaan esimerkiksi, että kokonaisvaikutus metsäteollisuuteen on aikaisempien selvitysten mukaan suhteellisen vähäinen, mutta suuret paikalliset ja alueelliset ja vaikutukset ovat mahdollisia. Tätä käsitellään loppuraportissa.
} 
Valtion tukitoimet kielletään 1. tammikuuta 2015 jälkeen. Sen vuoksi Pohjoismaiden hallitusten on toimittava nopeasti, mikäli ne aikovat helpottaa siirtymävaihetta tukitoimin. Suomi on perustanut valtion rahoittaman tukiohjelman vuosiksi 2013 ja 2014. Norja helpottaa sopeutumista NOx-rahastolla, joka on sektorin rahoittama ja jota ei sen vuoksi katsota valtiontueksi.

EU:lla on useita ohjelmia, jotka voivat osallistua muutoksen rahoittamiseen. Meneillään olevat EU:n rakennerahaston tukea koskevat kumppanuusneuvottelut tulevat vaikuttamaan Suomen, Ruotsin ja Tanskan mahdollisuuteen hakea rahoitusta tarvittavaan infrastruktuuriin vuosina 2014-2020.

Markkinat tulevat sopeutumaan uusiin määräyksiin. Kaikki yritykset eivät selviydy muutoksesta hengissä, ja muutoksella odotetaan olevan yhteiskuntataloudellisia seurauksia; kilpailukyvyn heikkeneminen ja työpaikkojen menetys.

Rahtialusten elinikä on noin 25 vuotta. Uusien aluksia rakennettaessa uudet rikkipäästömääräykset voidaan täyttää ilman merkittäviä lisäkustannuksia. Ongelmana ovat ne lukuisat alukset, jotka on rakennettu ja joita käytetään vanhojen, lievempien määräysten mukaisesti. On selvitettävä, miten suuria uudistuksia ja muutoksia on tehtävä rahtialuksiin, jotka huolehtivat vuoden 2015 jälkeen Itämeren meriliikenteestä ja mitä seurauksia uusilla määräyksillä on näille vanhemmille aluksille ja siten valtaosalle merenkulkua.

Varustamoilla on valittavanaan useita teknisiä vaihtoehtoja: dieselöljy ja muuntyyppiset puhtaammat polttoaineet, LNG, päästöjen puhdistaminen, kahden eri polttoaineen käyttäminen ja nopeuden alentaminen. On järkevää olla sitoutumatta yhteen ainoaan ratkaisuun. Ryhmä arvioi kuitenkin, että LNG (nesteytetty maakaasu) ja metanoli28 tulevat vastedes todennäköisesti olemaan Itämeren laivaliikenteen tärkeimmät polttoaineet, ja että siirtymävaiheessa turvaudutaan meridieseliin. LNG:n käyttöä koskevat määräykset ovat puutteelliset tai puuttuvat kokonaan, ja viranomaisten tulisi reagoida tähän pikaisesti. Työ LNG:n käsittelyä koskevan yhteisen kannan ja yhteisten määräysten kehittämiseksi on jo aloitettu29, mutta tuloksiin pääseminen vie aikaa. Ei ole myöskään olemassa yhteistä strategiaa kattavan LNGinfrastruktuurin rakentamiseksi Pohjoismaihin ja Itämeren alueelle. Näiden asioiden nopea toteutus ja edistyminen edellyttävät vahvaa poliittista tukea. Pohjoismaiden tulee priorisoida tätä tehtävää.

Dieselöljyn rajoitettu tarjonta ja korkea hinta saattavat olla siirtymävaiheessa haaste varustamoille. Dieselin korkeampi hinta vaikuttaa myös maantiekuljetuksiin. Määrä-

\footnotetext{
28 Metanolin leimahduspiste on 12 celsiusastetta, ja sen vuoksi sen käyttö on nykytekniikalla meridieselin käyttöä vaarallisempaa.

${ }^{29}$ Katso esimerkiksi raportti "North European LNG Infrastructure Project, Summary Report», Danish Maritime Authority, toukokuu 2012.
} 
ys meridieselin ja tavallisen dieselin erilaisesta leimahduspisteestä on harmillinen ja turha este, kuten USA:n IMOssa 2013 esittelemässä ehdotuksessa todetaan ${ }^{30}$.

Rikin ja typen oksidien uudet, aikaisempaa tiukemmat päästömääräykset ovat luoneet ja tulevat oletettavasti vastedeskin luomaan uusia mahdollisuuksia uudenlaisia ratkaisuja tarjoaville yrityksille. Typen oksideja koskevien määräysten täytäntöönpanon lykkääminen, jota IMOssa pohdittiin ${ }^{31}$, voisi haitata tätä.

On tärkeää estää vilpillinen toiminta, jotta voidaan varmistaa reilu kilpailu uusien määräysten tultua voimaan. Tämä edellyttää viranomaisvalvontaa. Tanska suunnittelee asentavansa erityisiä laitteita («sniffers»), jotka mittaavat ohi purjehtivien alusten rikkipäästöjä.

Norjan elinkeinoelämän vuonna 2008 perustamasta ja rahoittamasta NOxrahastosta on saatu erittäin myönteisiä kokemuksia. Rahasto rahoittaa päästöjen rajoittamistoimia ja helpottaa siten sopeutumista uusiin rikki- ja typpimääräyksiin. NOx-rahaston kokemukset osoittavat, että ympäristömaksut kannattaa ohjata pikemminkin kyseisten ympäristöongelmien ratkaisemiseen kuin valtion tulojen kasvattamiseen. Ryhmä katsoo, etteivät muut Pohjoismaat voi hyödyntää NOxrahastomallia lyhyellä aikavälillä. Kokemukset kuitenkin osoittavat, että taloudelliset kannusteet helpottavat siirtymistä puhtaampiin tekniikoihin merenkulussa, ja muiden Pohjoismaiden kannattaa ottaa oppia NOx-rahastosta luodessaan omia kannustemallejaan.

Pelko tavarakuljetusten siirtymisestä mereltä maanteille on aiheellinen. Se lisäisi ruuhkaongelmia ja ympäristön kuormitusta. Tässä yhteydessä huomattakoon, että EU:n liikennepolitiikan valkoisessa kirjassa tavoitteeksi on asetettu, etteivät yli 300 kilometrin pituiset tavarakuljetukset kulkisi lainkaan maanteitse. Ryhmä ei pidä tieliikenteen lisämaksuja poliittisena vaihtoehtona, muun muassa siitä syystä, että maantiekuljetuksille ei monesti ole mitään vaihtoehtoa, esimerkiksi PohjoisSuomessa. Satama- ja/tai väylämaksujen alentaminen saattaisi vahvistaa merenkulun kilpailuasemaa suhteessa tiekuljetuksiin.

Aiempana kuvaillun nojalla työryhmä suosittaa elinkeinovaliokunnalle ja ympäristöja luonnonvaravaliokunnalle, että ne laativat valiokuntaehdotuksen Pohjoismaiden neuvoston lokakuussa 2013 pidettävän Oslon-istunnon käsiteltäväksi ja että ehdotus sisältää seuraavat suositukset:

\footnotetext{
${ }^{30}$ International Maritime Organisation (IMO), Maritime Safety Committee's 92nd session, agenda item 10, Comments on document MSC 92/10 submitted by the United States. 31 IMOn työryhmät ovat käsitelleet ehdotusta sääntelytoimien täytäntöönpanon lykkäämisestä. Tämä on huolestuttanut yrityksiä, jotka tuottavat uusia tekniikoita vanhan, saastuttavamman tekniikan tilalle.
} 
a. että Pohjoismaiden hallitukset ryhtyvät toimenpiteisiin merenkulun kilpailukyvyn ylläpitämiseksi ja vahvistamiseksi

b. että Pohjoismaiden hallitukset tekevät yhteistyötä luodakseen yhteiset säännöt nesteytetyn maakaasun (LNG) käytölle Pohjoismaissa ja kansainvälisesti ja että Pohjoismaiden hallitukset laativat kansalliset suunnitelmat LNG-terminaalien perustamiseksi Pohjoismaiden satamiin

c. että Ruotsin, Suomen ja Tanskan hallitukset sisällyttävät meriliikenteen infrastruktuurin, mukaan lukien LNG-terminaalien, rahoituksen EU:n rakennerahaston tuesta solmittaviin kumppanuussopimuksiin kaudella 2014-2020

d. että pyrkivät edistämään meridieselin leimahduspistettä koskevien sääntöjen muuttamista tavallista dieseliä vastaaviksi

e. että Pohjoismaiden hallitukset pyrkivät EU:ssa, IMOssa ja muissa olennaisissa kansainvälisissä yhteyksissä siihen, että Itämerellä, Kattegatissa ja Pohjanmerellä sekä Pohjois-Amerikan rannikolla voimassa olevat rikkipäästösäännöt tulisivat mahdollisimman pian voimaan myös muilla merialueilla

f. että Norjan, Ruotsin ja Suomen hallitukset koordinoivat ja priorisoivat suunnitelmien toteuttamista pohjoisten alueiden raideliikennekapasiteetin vahvistamiseksi ja laajentamiseksi sekä rautatieyhteyksien rakentamiseksi SECA-alueen ulkopuolisiin satamiin Pohjoismaissa, kuten Narvikiin ja Trondheimiin

g. että Ruotsin ja Suomen hallitukset tutkivat, mitä seurauksia rikkidirektiivin täytäntöönpanolla on erityisen haavoittuville sektoreille rajoitetuilla maantieteellisillä alueilla, ja onko siirtymävaiheessa mahdollista käynnistää erityisiä alueellisia toimenpiteitä, joiden avulla vältettäisiin rikkidirektiivin täytäntöönpanon kielteiset vaikutukset paikalliseen ja alueelliseen talouteen

h. että Pohjoismaiden hallitukset kehittävät norjalaisen NOx-rahaston kokemusten pohjalta taloudellisia kannustimia puhtaamman tekniikan käyttöönottamiseksi meriliikenteessä

i. että Pohjoismaiden hallitukset selvittävät maiden nykyisen aluskannan saadakseen käsityksen rikkidirektiivin täytäntöönpanon edellyttämien muutosten laajuudesta. 


\section{Liite}

Elinkeinovaliokunnan ja ympäristö- ja luonnonvaravaliokunnan yhteisessä kokouksessa Reykjavikissa 29. tammikuuta 2013 päätettiin, että jokaisen maan valtuuskunta lukuun ottamatta Islantia, Färsaaria ja Grönlantia nimeää edustajan uuteen työryhmään, joka ryhtyy käsittelemään EU:n rikkidirektiivin täytäntöönpanoon liittyviä ongelmia.

\section{Ryhmän kokoonpano}

Työryhmässä ovat olleet mukana seuraavat henkilöt: Oskar Grimstad (Norja), Anders Eriksson (Ahvenanmaa), Eero Suutari (Suomi), Thomas Danielsen (Tanska) ja Billy Gustafsson (Ruotsi). Oskar Grimstad on toiminut ryhmän puheenjohtajana ja Anders Eriksson varapuheenjohtajana. Tryggvi Felixson ja Johan Lindblad Pohjoismaiden neuvoston sihteeristöstä Kööpenhaminasta ovat toimineet työryhmän sihteeristönä. Yksittäisillä edustajilla on ollut kokouksissa mukanaan lisäjäseninä kansallisia virkamiehiä.

\section{Ryhmän toimeksianto}

Ryhmä sai tammikuussa 2013 pidetyssä kokouksessa seuraavan toimeksiannon:

Arvioida Pohjoismaiden mahdollisia yhteisiä toimenpiteitä, joilla helpotetaan rikkidirektiivin täytäntöönpanon vaikutuksia Itämeren, Kattegatin ja Pohjanmeren merenkulkuun, ja laatia ehdotus Pohjoismaiden neuvoston yhteiseksi aloitteeksi.

Työryhmän tehtävänä on selvittää mahdollisuudet uusien tekniikoiden kokeilujaksoihin tai muihin siirtymäkauden järjestelmiin rikkidirektiivin tullessa voimaan vuonna 2015. Lisäksi sen tulee selvittää ja vertailla olemassa olevia sekä kansallisia että EU:n tukiohjelmia, joita varustamot voivat hyödyntää alusten siirtyessä rikin ja typen oksidien päästöjä vähentäviin uusiin tekniikoihin.

Työryhmän tulee arvioida Pohjoismaiden mahdollisia yhteisiä toimenpiteitä, joilla helpotetaan rikkidirektiivin täytäntöönpanon vaikutuksia Itämeren, Kattegatin ja Pohjanmeren merenkulkuun ja laatia ehdotus Pohjoismaiden neuvoston tätä koskevaksi aloitteeksi.

Työryhmän kokouksessa Maarianhaminassa 24. kesäkuuta 2013 todettiin, etteivät tehtävässä mainitut kokeilujaksot ole mahdollisia, minkä kumpikin valiokunta hyväksyi niille toimitetussa erityisessä osaraportissa.

\section{Ryhmän kokoukset ja toiminta}

Ryhmän ensimmäinen kokous, järjestäytymiskokous pidettiin Tukholmassa 10. huhtikuuta. Saadakseen perusteellisen selvityksen ja esittelyn koko ongelmakentästä ryhmä oli kutsunut kokoukseen Västernorrlandin lääninhal- 
lituksen projektijohtajan Per-Åke Hultstedtin, joka on johtanut projektia ja kirjoittanut raportin rikkidirektiivistä selvittäen ongelmakenttää ennen kaikkea pohjoisruotsalaisesta ja osittain pohjoissuomalaisesta näkökulmasta. Työryhmä päätti tässä kokouksessa myös työsuunnitelmastaan. Se sopi pitävänsä vielä kolme kokousta ja selvittävänsä kussakin kokouksessa erityisesti tiettyjen Pohjoismaiden ja lähialueiden tilannetta. Ensimmäisessä kokouksessa keskityttiinkin erityisesti Ruotsin määräyksiin ja tilanteeseen.

Ryhmän toinen kokous pidettiin videokokouksena 23. toukokuuta. Sihteeristö oli laatinut kokoukseen muistion kansallisista tukiohjelmista ja EU:n tukiohjelmasta. Kutakin maata kuvailtiin lyhyesti. Sihteeristö oli myös laatinut kokoukseen aineistoa teknisistä ratkaisuista, joita varustamot voivat käyttää täyttääkseen uudet rikkipäästövaatimukset. Keskustelua käytiin myös maantiekuljetusten ja merikuljetusten välisestä kilpailutilanteesta ja maantiekuljetusten lisääntymisen uhasta.

Ryhmän kolmas kokous pidettiin Maarianhaminassa 24. kesäkuuta. Ryhmä oli kutsunut kokoukseen Suomen varustamoyhdistyksen edustajia kertomaan oman näkemyksensä ongelmasta, Viking Linen teknisen johtajan kertomaan LNG:stä (Liquid Natural Gas - nesteytetty maakaasu) tulevaisuuden mahdollisena polttoaineena ja BSPC:n meripolitiikan raportoijan selostamaan lähemmin BSPC:n tämän alueen työtä. Lisäksi keskusteltiin tieliikenteen edellytyksistä, potentiaalista siirtää kuljetuksia tulevaisuudessa entistä enemmän mereltä rautateille sekä muiden Itämeren-maiden tukitoimista yritysten ja varustamojen auttamiseksi vuotta 2015 edeltävän siirtymäkauden aikana. Maarianhaminan-kokouksessa keskusteltiin myös rikkityöryhmän kummallekin valiokunnalle toimitettavan raportin ensimmäisestä luonnoksesta.

Ryhmän neljäs kokous pidettiin Kööpenhaminassa 28. elokuuta, ja siinä keskityttiin Tanskan ja Norjan tilanteeseen. Kokoukseen oli kutsuttu Danske Maritimen (Tanskan merenkulkuvaruste- ja laivanvalmistajien toimiala- ja työnantajajärjestö) sekä Fjord 1:n (norjalainen lauttayhtiö) edustajat. Ulkopuolisten alustajien esitykset vahvistivat ryhmän työn kuluessa jo saamaa kuvaa ongelmakentästä ja mahdollisista toimenpiteistä. Kokouksessa käytiin uudelleen läpi työryhmän ehdotus kummallekin valiokunnalle esitettävästä loppuraportista ja toimenpide-ehdotuksista, jotka valiokunnat voivat esittää Pohjoismaiden neuvostolle, joka puolestaan voi sen jälkeen osoittaa ne Pohjoismaiden hallituksille. Työryhmä pitää lisäkokouksia vain jos se on välttämätöntä.

Työryhmä katsoo suorittaneensa tehtävänsä loppuun toimitettuaan loppuraportin valiokunnille.

Kaikissa kokouksissa on ollut tulkkaus skandinaavisten kielten ja suomen välillä, mutta kirjallista aineistoa ei ole yleensä käännetty suomeksi. 


\section{Viitteet}

- Työ- ja elinkeinoministeriö. 2013. LNG-terminaalien investointituki. http://www.tem.fi/energia/lng-terminaalien investointituki

- Danish Maritime Authority. 2012. North European LNG Infrastructure Project. Summary Report.

- Danske Maritime. 28. elokuuta 2013. Esitys työryhmän kokouksessa Kööpenhaminassa.

- Viro. Sähköposti: Silver Vahtra, Counsellor Marine Environment Dept. Estonian Ministry of the Environment

- European Commission. 2011. Commission Staff Working Paper: Pollutant Emission Reduction from Maritime Transport and the Sustainable Waterborne Transport Toolbox. Brussels: European Commission.

- European Commission. Trans-European Transport Network Executive Agency (TEN-T EA). http://tentea.ec.europa.eu/en/home/

- European Commission. 2012. Regional Policy - Inforegio. The Funds: European Development Fund.

http://ec.europa.eu/regional policy/thefunds/regional/index en.cfm

- Helsinki Commission. Emissions from ships. http://www.helcom.fi/shipping/emissions/en GB/emisions/

- International Maritime Organisation (IMO). Maritime Safety Committee's 92nd session. Agenda item 10. Comments on document MSC 92/10 submitted by the United States.

- Jordal-Jørgensen, Jørgen. 2012. Reducing Air Pollution from Ships. A cost benefit analysis and feasibility study on possible means for further reduction of emissions. Raportti/Danish Ministry of the Environment. Kööpenhamina: Ympäristöhallitus.

- Liikenne- ja viestintäministeriö. Lehdistötiedote: Alusten investointituesta helpotusta rikkipäästörajoihin sopeutumiseen 14.03.2013 http://www.lvm.fi/tiedote/4142361/alusten-investointituestahelpotusta-rikkipaastorajoihin-sopeutumiseen 
- Ljungberg, Anders et. al. 2013. Konsekvenser av skärpta krav för svavelhalten I marint bränsel - delredovisning. Rapport/Trafikanalys 2013:7. Tukholma: Trafikanalys.

- Martinsen, Kjetil \& Torvanger, Asbjørn. 2013. Control mechanisms for Nordic ship emissions. Raportti/TemaNord 2013:518. Kööpenhamina: Pohjoismaiden ministerineuvosto.

- Tanskan ympäristöministeriö. Ecoinnovation. Ambitiøs handlingsplan for renere skibsfart (Puhtaamman merenkulun tavoitteellinen toimintasuunnitelma).

http://www.ecoinnovation.dk/Emneoversigt/Partnerskaber miljøtekno logi/Partnerskabet for renere skibsfart/Ambitioes handlingsplan.htm

- Miola, Apollonia et. al. 2010. Regulating Air Emissions from Ships. The State of Art on Methodologies, Technologies and Policy Options. Rapport/European Commission. Luxembourg: Publications Office of the European Union.

- Næringslivets Hovedorganisasjon (NHO) - Norjan työnantajien keskusjärjestö. www.nho.no

- Norjan varustamoyhdistys. 24. kesäkuuta 2013. Esitys työryhmän kokouksessa Ahvenanmaalla.

- Euroopan unionin virallinen lehti. 2012. Euroopan parlamentin ja neuvoston direktiivi 2012/33/EU, annettu 21 päivänä marraskuuta 2012, neuvoston direktiivin 1999/32/EY muuttamisesta meriliikenteessä käytettävien polttoaineiden rikkipitoisuuden osalta. $\underline{\mathrm{http}}$ ///eurlex.europa.eu/LexUriServ/LexUriServ.do?uri=0J:L:2012:327:0001:0 013:FI:PDF

- Saksa, sähköpostivastaus: Holger Steinbock BG Verkehr/BG for Transport and Traffic. Dienststelle Schiffssicherheit/Ship Safety Division

- Söfartsverket Sverige (Ruotsin merenkulkulaitos), Konsekvenserna av IMO:s nya regler för svovelhalt i marint bränsle, 2009-05-14. Raportti. 